\title{
R. $V$. MANN: FURTHER DOWN THE SLIPPERY SLOPE
}

\author{
JOSEPH R. MARIN"
}

\begin{abstract}
It is the function of the legislature, not the courts, to authorize arbitrany police action that would otherwise be unlawful as a violation of rights traditionally protected at common law... With respect, the majority of the Court departs firm ground for a slippery slope when they authorize an otherwise unlawful interference with individual liberty by the police, solely on the basis that it is reasonably necessary to carny out general police duties.
\end{abstract}

— Chief Justice Dickson's dissent in R. v. Dedman'

\section{INTRODUCTION}

The words of former Chief Justice Dickson have proven accurate as the ancillary powers doctrine developed in Dedman continues to resonate throughout the law of criminal procedure. In the much anticipated case of $R . v$. Mann, ${ }^{2}$ the Supreme Court of Canada was called upon to decide whether the common law police power to conduct investigative detentions, created just over a decade ago by the Ontario Court of Appeal, ${ }^{3}$ would remain a fixture of Canadian law. The Court gave the new power its blessing. In so doing, the Supreme Court of Canada has chosen a path that, barring legislative intervention, seems destined to lead to an incremental expansion of police powers and a corresponding reduction in the rights of Canadians to walk the streets free from police interference. ${ }^{4}$

\section{JI. CASE HISTORY}

The case against Phillip Mann originated in an incident just outside of downtown Winnipeg on 23 December 2000. Two police officers received a radio dispatch alerting them to a break and enter in progress. The dispatch described the suspect as Zachary Parisienne, a 21-year-old Aboriginal man who was last seen wearing a black jacket with white sleeves. The police officers proceeded to the neighbourhood of the reported crime and spotted the accused walking along the sidewalk. The officers later testified that Mann fit the description of the suspect "to the tee."

Mann was detained and asked to identify himself. He complied and was subjected to a patdown search. The officer carrying out the search later testified that he felt "something soft"

Third year law student, Faculty of Law, McGill University, Montreal, Quebec.

[1985] 2 S.C.R. 2 at paras. 25,30 [Dedman].

R. v. Mann. [2004] 3 S.C.R. 59 [Mann].

R. v. Simpson (1993), 12 O.R. (3d) 182 (Ont. C.A.) [Simpson].

Detentions short of arrest were almost certainly a fixture of police practice before investigative detentions were condoned by the courts (see e.g. Alan Young, "All Along the Watchtower: Arbitrary Detention and the Police Function" (1991) 29 Osgoode Hall L.J. 329 at 341). However, the U.S. experience suggests that the judicial endorsement and regulation of such formerly illegal detentions can have a negative effect on the freedom of citizens (see e.g. Tracey Maclin, "The Decline of the Right of Locomotion: the Fourth Amendment on the Streets" (1990) 75 Cornell L. Rev. 1258).

3. Mann, supra note 2 at paras. 4-5.

. R. v. Marn (2002), 166 Man. R. (2d) 260 at 262 (Man. C.A.) [Mann 2002]. 
in the front kangaroo pocket of the accused's sweater and decided to search the pocket. The pocket contained a sizeable quantity of marijuana and some small plastic bags. Mann was arrested and charged with possession of marijuana for the purposes of trafficking.

At trial, defence counsel argued that the marijuana was inadmissible as evidence against the accused because it was the product of an illegal search. The Trial Court held that the investigative detention and pat-down search for weapons were authorized. However, the officers lacked a "reason to go beyond the pat down search," which made their search of the accused's pockets unreasonable and therefore in breach of 5.8 of the Charler. ${ }^{8}$ The Court excluded the evidence in accordance with s. 24(2) of the Charter.

The Manitoba Court of Appeal reversed the Trial Court's findings and held that the marijuana was admissible evidence. It found that both the detention and pat down search were authorized. Relying on the testimony of one of the officers that he searched inside Mann's pocket "because [he felt] something soft ... in the front, ... hiding something hard behind, another weapon," the Appellate Court held that there were reasonable grounds to extend the pat-down search to include a search of the pocket and that the "search for weapons was conducted in good faith." 10 The pocket search therefore did not infringe 5.8 and the marijuana was admissible as evidence.

The accused appealed to the Supreme Court of Canada. Two primary issues were raised on appeal: "(i) whether there exists, at common law, a police power to detain individuals for investigative purposes; and (ii) if so, whether there exists a concomitant common law power of search incident to such investigative detentions."

\section{A BRIEF HistoRy OF INVESTIGA TIVE DETENTIONS}

Section 9 of the Criminal Code expressly prohibits the creation of new common law crimes. ${ }^{12}$ While ostensibly heeding this prohibition, the courts have engaged in interpretive exercises that have arguably created new common law crimes. ${ }^{13}$ There is no counterpart to the prohibition in s. 9 in the realm of criminal procedure; on the contrary in Dedman, a majority of the Supreme Court of Canada explicitly endorsed a role for the common law in creating police powers above and beyond those enumerated in the Code. Justice Le Dain in Dedman purported to apply the English Court of Criminal Appeal case of $R$. $v$. Waterfield ${ }^{14}$ to create a two step test for determining if a particular police action that interferes with an individual's liberty is justified at common law as an ancillary power to a police duty. The first step is to ask whether the officer's conduct falls within the general scope of a statutory

Mann, supra note 2 at para. 9.

Canadian Charter of Rights and Freedoms, Part I of the Constitution Act, 1982, being Schedule B to the Canada Act 1982 (U.K.), 1982, c. 11, ss. 8, 24(2) [Charter].

Mann 2002, supra note 6.

Mann 2002, supra note 6 at 268.

Mann, supra note 2 at para. 2.

R.S.C. 1985 , c. C-46, s. $9[$ Code].

See e.g. R. v. Jobidon, [1991] 2 S.C.R. 714 at 774, Sopinka J. ("The effect of my colleague's approach is to create an offence where one does not exist under the terms of the Code by application of the common law").

is (1963) 3 All E.R. 659 [Waterfield] 
or common law police duty. ${ }^{15}$ If the first step is met, the second stage is an inquiry into whether the officer's action was nonetheless an unjustifiable use of the powers associated with that duty. ${ }^{16}$

Justice Le Dain went on to define the duties of police officers at common law in extremely broad terms as "the preservation of peace, the prevention of crime and the protection of life and property." " He defined the second step as a reasonableness inquiry: "[T]he interference with liberty must be necessary for the carrying out of the particular police duty and it must be reasonable, having regard to the nature of the liberty interfered with and the importance of the public purpose served by the interference." 18

There is no statutory police power of detention other than the power to make an arrest, which is set out in the Code. To make a lawful arrest without a warrant, a police officer must have "reasonable grounds to believe" that a person has committed or is about to commit an offence. ${ }^{19}$ Following Dedman, the Ontarjo Court of Appeal in Simpson ${ }^{20}$ used the Waterfield test to find that investigative detentions - detentions short of arrest - are justified at common law if a police officer has an "articulable cause"21 for believing that a person is "criminally implicated in the activity under investigation",22 a threshold the Court considered to be lower than the reasonable and probable grounds standard for arrests. ${ }^{23}$ The Court of Appeal defined "articulable cause" as "reasonable grounds to suspect" that the detainee is criminally implicated based on "a constellation of objectively discernable facts." as a second step, the detention also had to be justifiable based on an assessment of "the totality of the circumstances."2s

In the intervening decade between Simpson and the Supreme Court of Canada decision in Mann, appellate courts in every province have followed Ontario's lead and recognized the legality of investigative detentions. ${ }^{26}$

Arrests have been recognized as carrying with them certain incidental powers at common law. Chief among these is the power to search incidental to arrest. The Supreme Coun of Canada in Cloutier v. Langlois held that a search incidental to arrest could be justified by a need to search for weapons or to preserve evidence. ${ }^{27}$ This begs the obvious question of whether investigative detentions also carry with them an incidental search power, and if so.

Dedman, supra note 1 at para. 68 .

Ibid. at para. 69.

bid. at para. 14.

lbid. at para. 69.

Code, supra note 12, s. 495(1).

Supra note 3.

Simpson borrowed the phrase "articulable cause" from U.S. case law following the decision of the U.S. Supreme Court in Tern' v. Ohio, 392 U.S. 1 (1968) [Terry]. Detentions based on "articulable cause" in the U.S. are known as "Tern stops" (James Stribopoulos, "A Failed Experiment? Investigative Detentions: "len Years L.ater" (2003) 41 Alta. L. Rev. 335 at 347, n. 50).

Simpson, supra note 3 at para. 61.

tbid. at para. 63.

lbid. at para. 61.

lbid. at para. 66.

Stribopoulos, supra note 21 at 361 , n. 119 .

[1990] I S.C.R. 158 at 188-89. 
what the scope of that power is. Prior to the Mann decision, five of the nine provincial appellate courts had recognized some form of search power incidental to investigative detention. ${ }^{28}$

Apart from the power to search incidental to investigative detentions, several other issues were raised by the introduction of a new police power to detain. ${ }^{29}$ The first set of issues concerns the nature of the rights of detainees under s. 10 of the Charter. Further issues include: (1) how long can a detainee be held before the police officer is compelled to release or arrest him; (2) can the detainee be moved from the scene of the initial detention without first being arrested; and (3) is a police officer entitled to use force in making good a detention and, if so, how much force is acceptable?

\section{Discussion OF THE SUPREME COURT OF CaNADA'S JUDGMENT IN R. V. MANN}

Justice lacobucci, writing for the majority of the Supreme Court of Canada in Mann, began with a statement that "the issues in this case require the Court to balance individual liberty rights and privacy interests with a societal interest in effective policing." ${ }^{30} \mathrm{He}$ noted that "[a]bsent a law to the contrary individuals are free to do as they please" in contrast to the police who "may act only to the extent that they are empowered to do so by law." 31 Justice lacobucci then went on to analyze whether the law empowers police offers to conduct investigative detentions.

\section{A. Does a Common laiv Police Power to Detain for tile PURposes of Investigation Exist at COMmon Law?}

Sections 9 and 10 of the Charter offer constitutional guarantees against arbitrary detention and set out rights associated with detentions, respectively. The Court in Mann held that these rights are engaged only by police initiated "delays" that involve "significant physical or psychological restraint." 32 Detentions will not be arbitrary if they are authorized by law. Since there is no statutory law authorizing investigations short of arrest, the Court reasoned that such detentions will be lawful only if carried out in accordance with the common law. ${ }^{33}$

Justice lacobucci stated that while it was not "appropriate for [the] Court to recognize a general power of detention for investigative purposes," ${ }^{34}$ he did endorse the incremental development at common law of a "limited police power of investigative detention." "Ts The Supreme Court of Canada approved of the Court's application of the Waterfield test in Simpson to recognize a common law power of investigative detentions. However, lacobucci

Stribopoulos, supra note 21 at 361 , 12. 119

See generally Stribopoulos, ibid, and Leslic $\Lambda$. McCoy. "Liberty's Last Stand? Tracing the Limits of Investigative Detention" (2002) 46 Crim. L.Q. 319 at 323. 
J. rejected the "articulable cause"36 standard in Simpson in favour of one premised on a "reasonable grounds to suspect." ${ }^{37} \mathrm{He}$ held that in addition to a threshold assessment based on reasonable grounds, a detention must pass a second stage inquiry in order to comply with the second prong of Waterfield:

[T] circumstances, most notably the extent to which the interference with individual liberty is necessary to perform the officer's duty, the liberty interfered with, and the nature and extent of that interference, in order to meet the second prong of the Waterfietd lest. ${ }^{38}$

\section{B. IS There a Power to Sfarcil InCident to Investigative Detrintions?}

A search incident to an investigative detention is a warrantless search. ${ }^{39}$ Warrantless searches are prima facie unreasonable, and thus in breach of s. 8 of the Charter, unless they can be justified by the three step test in $R$. v. Collins. ${ }^{\text {to }}$ In order to be reasonable: (1) the search must be authorized by law; (2) the law must be reasonable; and (3) the search must be carried out in a reasonable manner."

Justice lacobucci applied the Collins test to searches incidental to investigative detentions and described the analysis as a balancing exercise where "the competing interests of an individual's reasonable expectation of privacy [are balanced against] ... the interests of police officer safety." ${ }^{22}$

The Court again relied on the Waterfield test, this time to ground a finding that a search incidental to investigative detention is authorized by the common law and therefore in compliance with the first stage of the Collins test. Justice lacobucci found that the first prong of the Waterfield test was easily satisfied because a search incidental to investigative detention fell within the broad duty to protect life and property recognized in Dedman. ${ }^{43} \mathrm{He}$ held that such a search would not offend the second prong of the Waterfield test if the officer conducting the search "believe[s] on reasonable grounds that his or her own safety, or the safety of others, is at risk."

The reasonableness of the search under the second prong of the Waterfield test overlaps with the third step of the Collins test, which also requires that the search be carried out in a reasonable manner." Justice lacobucci concluded that "where a police officer has reasonable grounds to believe that his or her safety or that of others is at risk, the officer may engage in a protective pat-down search of the detained individual."

\footnotetext{
Ibid. at para. 33.

17 Ibid. at para. 45.

sk Ibid. at para. 34.

iv $\quad$ bid. at para. 36.

I" [1987] I S.C.R. 265 [Collims]

$4 \quad$ lbid at 278.

J: Mann, supra nole 2 at para. 37.

4 Ibid. at para. 38.

'Ibid. at para. 40.

$\$ \quad$ bid. at para. 44.

4. Ibid. at para. 45.
} 
In the case at bar, the detention was reasonable because the accused fit the description of the suspect and was observed in close proximity to the location of the reported break and enter. The initial pat-down search was based on reasonable grounds because the officers had reasonable grounds to believe that the suspect would be "in possession of break-and-enter tools, which could be used as weapons." 47 However, when the officer reached into the accused's pocket after fecling a soft object inside, the search became "an unreasonable violation of the [a]ppellant's reasonable expectation of privacy in the contents of his pockets," ${ }^{48}$ and therefore infringed the accused's s. 8 Charter rights. Justice lacobucci agreed with the trial judge that "there was nothing from which [the officer could] infer that it was reasonable to proceed beyond a mere pat down search for security reasons." ${ }^{49}$ The Court concluded that the violation of s. 8 was sufficientiy serious to exclude the evidence under s. 24(2). . $^{\text {so }}$

\section{ANALYSIS}

In the intervening decade between Simpson and Mann, much ink has been spilled in an effort to discredit the common law police power of investigative detention and to urge the Supreme Court of Canada to put an end to the doctrine. Several commentators have argued that while a limited police power to detain short of arrest may be desirable, it is the proper purview of Parliament and not of the courts to create such a power." Others have condemned the power of investigative detention, regardless of its source. ${ }^{32}$ Now that the Supreme Court of Canada has chosen to ignore these warnings and has recognized a common law power of investigative detention, I propose to analyze Mann in light of questions raised in the commentary, and to ask whether the specific holdings in the case satisfactorily address the concerns of commentators.

\section{A. Articulable Cause vs. Reasonable Grounds to Suspect}

The Court in Simpson began with the premise that investigative detentions have long been a reality in Canada and should be regulated. Justice Doherty stated:

I have no doubt that the police delain individuals for investigative purposes when they have no basis to arrest them. In some siluations the police would be regarded as derelict in their duties if they did not do so. I agree with Professor Young, "All Along the Watch Tower", supra, at p. 367, when he asserts:

The courts must recognize the reality of investigatory detention and begin the process of regulating the practice so that street detentions do not end up being non-stationhouse incommunicado arrests. 
Unless and until Parliament or the Legislature acts, the common law and specifically the criteria formulated in Waterfield, supra, must provide the means whereby the courts regulate the police power to detain for investigatory purposes. $^{53}$

James Stribopoulos argues that as an attempt to regulate the behaviour of police officers, Simpson should be judged a failure. He criticizes the "articulable cause" standard as being so vague and open-ended as to offer "little meaningful direction to police." St Stribopoulos states that the Simpson judgment "proceeds with an exaggerated sense of both the ability of the police to recognize, and their desire to respect, the difference between mere suspicion, articulable cause (that is, reasonable suspicion), and reasonable and probable grounds." warns that "the standard will serve as a pliable measurement against which to construct reasons justifying those groundless stops that happen to yield evidence and which may need to be defended in court as a result." 96

Mann changed the standard for investigative detentions from "articulable cause" to "reasonable grounds to suspect" but did little to clarify the content of the new standard. It held that the "detention must be viewed as reasonably necessary on an objective view of the totality of the circumstances, informing the officer's suspicion that there is a clear nexus between the individual to be detained and a recent or on-going criminal offence."

The Supreme Court of Canada explained its decision to change from "articulable cause" to "reasonable grounds to suspect" by stating that it wanted to move away from the U.S. language towards a phrase that "Canadian jurisprudence has employed ... in analogous circumstances and has provided useful guidance to decide the issues in question." Is It scems unlikely that replacing Simpson's "constellation of objectively discernible facts" Mann's "objective view of the totality of the circumstances" will provide additional gujdance to police in the field - the difference between the reasonable grounds to believe required for an arrest and the presumably lower threshold of reasonable grounds to suspect required for an investigative detention is unclear.

\section{B. Potential for Etinic Profiling to Inform DECISIONS TO DETAIN}

Jerome Skolnick observes that "whenever rules of constraint are ambiguous, they strengthen the very conduct they are intended to restrain." Several commentators have argued that an investigative detention power based on a malleable standard such as "articulable case" could lead to an exacerbation of the problem of ethnic profiling. ${ }^{62}$ The

Simpson, supra note 3 at paras. 52-53.

Stribopoulos, supra note 21 at 355

Ibid.

Ibid. al 356.

Mam, supra note 2 at para. 34.

lbid. at para. 33.

Simpson, supra note 3 at para. 61 .

Mann, supra note 2 at para. 34.

Jerome H. Skolnick, Justice Withou Trial: Law Enforcement in Democratic Society, $3 \mathrm{~d}$ ed. (New York: Macmillan, 1994) at 12, cited in Stribopoulos, supra note 19 at 356.

See generally Stribopoulos, supra note 21 and Quigley, supra note 52. 
Court in Simpson was aware of concerns that investigative detentions might lead to discriminatory police practices, but it was confident that its approach to investigative detentions would rule out the possibility that mere subjective "hunches" that mask "irrelevant factors such as the detainee's sex, colour, age, ethnic origin or sexual orientation"63 could be used as a justification to detain. However, Quigley suggests that developments in the U.S. courts, which apply the same articulable cause/reasonable suspicion standard as Simpson, give us reason to fear that "the low standard of a reasonable suspicion can ... lead to greater scrutiny for minorities than for the majority community."

David Harris describes how the U.S. case law on Terry stops has evolved:

During the next Iwenty-five years, many cases fleshed out Terry's rules. These cases gradually required less and less evidence for a slop and frisk. A substantial body of law now allows police officers to stop an individual based on just two factors: presence in an area of high crime activity and evasive behavior. In other words, many courts now find that reasonable suspicion to stop exists when the person involved I) is in a crome-prone location, and 2) moves away from the police. ${ }^{6.5}$

It is clear how an ambiguous standard could disproportionately affect minorities living in crime prone inner city neighbourhoods. Quigley states that the effect in the U.S. "has been to institutionalize a great deal more scrutiny of Blacks and other minorities.".66

There is evidence that the same phenomenon may be happening in Canada. Stribopoulos cites empirical studies suggesting that "Aboriginals and blacks are stopped by police at considerably higher rates than members of other racial groups. " ${ }^{67}$ He states that "studies serve to reveal an unfortunate truth: in carrying out proactive stops, Canadian police sometimes use race as a substitute for objectively reasonable grounds."

The Supreme Court of Canada in Mann seemed to be aware of these concerns when it held that the presence of an individual in a high crime neighbourhood is only relevant to a decision to detain to the extent that it relates to the individual's "proximity to a particular crime." ${ }^{\circ 9}$ Justice lacobucci further stated that the "high crime nature of a neighbourhood is not by itself a basis for detaining individuals." ${ }^{70}$ These comments would seem to preclude an adoption of the U.S. approach described by Harris. However, it should be noted that despite the Canadianization of the threshold test from "articulable cause" to "reasonable grounds," portions of lacobucci J.'s judgment were informed by explicit references to U.S. Terry stop jurisprudence. " By abandoning the "articulable cause" standard, while at the same time citing U.S. authorities with approval, the Supreme Court of Canada is sending out contradictory

Simpson, supra note 3 at para. 61 .

Quigley, supra note 52 at 946.

David A. Harris, "Factors for Reasonable Suspicion: When Black and Poor Means Stopped and Frisked" (1994) 69 ind. L.J. 659 at 660 [emphasis added and footnotes omitted].

Quigley, supra note 52 at 946.

Stribopoulos, supra note 19 at 342 [footholes omilted].

Ihid. al 343 .

Mann, stupra note 2 at para. 47 [emphasis added].

Ibid.

Ibid. at paras. 41-42. 
signals with respect to the role that U.S. jurisprudence will be permitted to play in fleshing out the Canadian investigative detention power in the coming years.

David Tanovich suggests that the second "totality of the circumstances" step of the Simpson test might have provided safeguards against discriminatory detentions. However. many judgments applying Simpson have entirely ignored this step:

Unfortunately, most of the post-Simpson jurisprudence has focused on the issue of reasonable suspicion to the exclusion of other relevant factors. Two faclors which are particularly relevant in the context of racial profiling include the nature of the offence being investigated and the nature of tie police investigation.

Mann re-emphasized the second stage of Simpson when it held that reasonable grounds is only the "front-end" of the investigative detention analysis and that an assessment of the reasonableness of a detention must take into account the overall circumstances. ${ }^{73}$ However. whether lower courts will ignore this instruction, as they did in the case of Simpson, remains to be seen.

\section{Search InCident to InVestigative Detention}

More worrying than the Supreme Court of Canada's endorsement of a power of investigative detention is its recognition of a search power incident to such detentions. As previously mentioned, in the years following Simpson, several provincial appellate courts have recognized a search power incidental to detentions. One line of cases created this power by analogy to the search power incidental to arrest; ${ }^{74}$ a Quebec Court of Appeal decision, in particular, allowed searches not only for the purpose of ensuring the safety of the detaining officer and the public but also for the purpose of securing evidence. ${ }^{75}$

The Mann decision implicitly rejected this line of authority when it emphasized "the importance of maintaining a distinction between search incidental to arrest and search incidental to an investigative detention." Iacobucci J. preferred to ground the new power in a second application of the Waterfield test to find that a detaining officer may conduct "a protective pat-down search of the detained individual." An incidental search for the purpose of preserving evidence would no longer seem to be appropriate.

However, commentators fear that a case-by-case common law approach to the development of an incidental search power will lead to an expansion of the power to the point

" David M. Tanovich, "Using the Charter to Stop Racial Profiling: The Development of an Equality-based Conception of Arbitrary Detention" (2002) 40 Osgoode Hall L.J. I45 at 174.

M Mann, stupra note 2 at para. 34.

"R. R. Murray (1997), 136 C.C.C. (3d) 197 (Qc. C.A.) [Afurray]: R v. Lake (1996), I13 C.C.C. (3d) 208 (Sask. C.A.), cited in Stribopoulos, supra note 21 at 363.64, n. 138-39.

Murray, ibid. at 212.

Mann, supro note 2 at para. 37.

lbid. at para. 45 . 
where it is virtually indistinguishable from a search incidental to arrest, despite the fact that it began as a narrow power to search for weapons. ${ }^{78}$

Steve Coughlan argues that experience with search incident to Terry stops in the U.S. has shown how a search conducted for safety reasons is not as narrow a justification as it might seem:

Certainty U.S. case law suggest that "sa fety reasons only" is not a stringent limitation. Rules allowing a search of a detainee's pockets only if a pal-down search creates reason to think the suspect might have a weapon fairly quickly permilted searches where an officer thought a lipstick container might be a shotgun shell or where an officer could think a soft object might be a rubber water pistol filled with acid. ${ }^{79}$

Stribopoulos finds that Canadian courts have moved even faster than their American counterparts in expanding the reach of searches incidental to investigative detentions. He cites a particularly alarming Alberta Court of Appeal decision which held that searching a suspect's pockets after a pat-down search was justified since a "bulky leather jacket provided the special reason for the more intrusive search. ${ }^{80} \mathrm{He}$ further notes that

Of course, heavy garments are commonplace in Alberta during much of the year. The same is true throughout most of Canada. On a practical level, this makes pocket searches the rule rather than the exception. ${ }^{81}$

Coughlan makes a similar objection to the Alberta decision, arguing that the case reduces s. 8 of the Charter to a "fair weather right."

Far from putting the breaks on this expansion, the Mann decision bestowed legitimacy on an incremental approach to the development of common law police powers. ${ }^{83}$ Therefore the trend of expanding powers of search incidental to detention will likely continue.

\section{LACUNAE IN THE, LAW}

In commenting on the evolution of investigative detentions since Simpson, Leslie McCoy notes that in many ways the law around the new power remains unsettled. First, she states that among the "most vexing questions relating to investigative detention is: how long is too long?"'s4 She notes that the "only guidance we have from the cases is that for it to be justified, an investigative detention must be "brief."'\$s Mann has done nothing to fill this lacuna in the law. Justice lacobucci merely restated that investigative detentions "must be of brief duration." 86

See generally Stribopoulos, supra note 21 and Coughian. supra note 52.

Coughlan, supra note 52 at 64 [footnotes omilted].

R. v. Waniandy (1995), 162 A.R. 293 at para. 4 (C. A.).

Stribopoulos, supres note 21 at 366.

Coughlan, supra note 52 at 65 .

Mann, supra note 2 at para. 17.

McCoy, supra note 29 at 323.

thid.

Mamn, supra note 2 at para. 22. 
McCoy further notes that the question of whether police officers are permitted to "transport the suspect to another location" decision that seemed to suggest that transporting a detainee to a police station "went beyond the scope of investigative detention": however, McCoy was unable to determine from the reasons whether the detention was unlawful because of transportation of the detainee or because of the length of the detention. ${ }^{88}$ Mann was absolutely silent on this issue, which is not surprising given that the case at bar involved no transportation of the detainee.

Finally, McCoy remarks on the fact that an investigative detainee's rights under s. 10 of the Charter have not been dealt with by the case law. ${ }^{89}$ With respect to s. 10(a), the Supreme Court of Canada did provide helpful guidance in Mann by holding that a detainee must be informed in "clear and simple language" ${ }^{\text {"⿻ }}$ of the reason for his detention.

In contrast, the Supreme Court of Canada's handling of the s. 10(b) right to counsel and to be informed of the right to counsel, provides a further example of why the common law is a poor instrument for regulating a police power. Justice lacobucci stated that he preferred to leave the s. $10(\mathrm{~b})$ issue "to another day." This is cool comfort to the hundreds or thousands of individuals who will be detained without being informed of their right to counsel while waiting for "another day." The right at stake is too fundamental to wait until a case whose facts more squarely address the issue winds its way to the Supreme Court of Canada. This aspect of the decision in Mann highlights the fact that courts are simply not competent to create complex regulatory regimes out of whole cloth. Unless the Court is prepared to stray well beyond the facts of a given case in order to set out a complete regulatory scheme in a rambling obiter dictum, issues such as those just raised can take many years of case law to settle.

Another outstanding question is whether force is permitted to make good a detention, and if so, how much. Coughlan notes that the Alberta Court of Appeal in R. v. Yum, ${ }^{92}$ went as far as to sanction the actions of a police officer who kicked a suspect in the chest in order to make good an investigative detention (the suspect was hiding under a parked car at the time). ${ }^{93}$ The Mann decision gave no guidelines on the amount of force that should be permitted.

\section{E. Investigative Detention: A Waterfield POWer or a Charter Power?}

Several commentators have criticized the use of Waterfield by the Supreme Court of Canada in Dedman and the Ontario Court of appeal in Simpson as the basis for creating new common law police powers. ${ }^{94}$ The accused in Waterfield was charged with assaulting a police officer and the two part test drafted by the English Court of Criminal Appeal was used for

McCoy, supra note 29 at 325.

Ibid. at 326.

lbid. at 327.

Mann, supra note 2 at para. 21.

Ibid. at para. 22.

(2001) 277 A.R. 238.

Coughlan, supra note 52 at 57 .

See Quigley, supra note 52 at 938-39: Stribopoulos, supra note 21 at 348-52. 
the limited purpose of determining if the assault had occurred while the officer was in the course of carrying out his duties. ${ }^{95}$ Stribopoulos criticizes the broad use of the test by Dedman and Simpson to create new police powers:

At least initially, Canadian courts had applied the Waterfield test in the same limited way as their English counterparts. The case was used to decide whether a police officer was acting "in execution of his duty" when an accused allegedly assaulted or obstructed him. In Canada, as in England, this is an essential element of each of these offences. Thus, at its inception the test allowed, at the very most, for nothing more than an incremental and indirect expansion of existing police powers, as individual cases presented themselves for consideration. This point is best illustrated by the limited way in which English courts have applied $W$ aterfield. The case has been cited infrequently, and its two-part test has never been used to justify the creation of an entirely new and invasive police investigative power. In fact, in one of the last English decisions that refers to Waterfield, the Court noted that while the "common law evolves" through "a delicate process," the creation of a new police investigative power would represent a "violent change," which is "a matter for Parliament rather than he courts." $" 96$

Stribopoulos goes on to note that the U.K. Parliament took up this invitation from the courts and created a comprehensive legislative scheme to permit but also to regulate a limited power of investigative detention. ${ }^{97}$

Tim Quigley echoes Stribopoulos' concerns with the application of Waterfield in Canada. He states:

Unfortunately, that Coun [Simpson] has not engaged in a comprehensive analysis, either of the precise holding in Waterfield itself or of its context... [T] [Tere is a great deal of difference between using the Waterfield approach to determine whether a police officer, already engaged in a duty imposed by statute or common law, has unjustifiably used the powers associated with the duty, and the more expansive approach in $\operatorname{Simpson}{ }^{98}$

If the investigative detention power created by Simpson rested on "questionable foundation[s],"99 the incidental search power created by Mann is a house of cards. The Supreme Court of Canada expressed such a high degree of confidence in the Waterfield test that it used it twice. Once to ground investigative detentions and a second time to ground searches incidental to those detentions. The search power created by Mann is an ancillary power incidental to an ancillary power — a second order Waterfield power.

A possible explanation for the lack of concern in Simpson and Mann with the actual holding in Waterfield is that Waterfield is not the true source of the new police powers that those decisions created. It is difficult to avoid the impression that the Court used the Charter itself to create these new powers. Mann not only changed the investigative detention threshold standard from "articulable cause" to "reasonable grounds to suspect," it also relied heavily on the concept of "reasonableness" when defining its new search power. Curiously,

Stribopoulos, ibid. at 348.

lbid. at 349-50 [footnotes omitted].

Police and Criminal Evidence Act 1984 (U.K.), 1984, c. 60 [PACE], cited in Stribopoulos, ibid. at 350 , n. 69.

4* Quigley, supra note 52 at 938-39.

Wtribopoulos, supra note 21 at 348 
neither the words "reasonable" nor "reasonableness" appear anywhere in the Waterfield judgment. Where the word reasonable does occur, of course, is in $\mathbf{s .} 8$ of the Charter, which enshrines the right to be free from "unreasonable search and seizure."

Ronald Delisle notes that the advent of the Charter has caused Canadian courts "to be much more creative with respect to the common law than in the past." ${ }^{100}$ Delisle argues that this isn't necessarily a bad thing; however, when the development of the common law ignores the purpose of Charter rights, namely "to protect the citizen from the government [and] not to authorize intrusions," 101 the results can be problematic. The purpose of the Charter is not to define an upper ceiling below which the courts can fill in state powers. However, this seems to be precisely how the Simpson and Mann courts have approached Charter interpretation. In so doing they have ignored the words of Dickson C.J.C. in Hunter v. Southam:

While the courts are guardians of the Constitution and of individuals' rights under it, it is the legislature's responsibility 10 enact legislation that embodies appropriale safeguards to comply with the Constitution's requirements. It should not fall to the courts to fill in the details that will render legislative lacunac constitutional. ${ }^{102}$

\section{Conclusion}

Justice lacobucci should have heeded his own advice when he stated that the Court "must tread softly where complex legal developments are best left to the experience and expertise of legislators ... [and that] major changes requiring the development of subsidiary rules and procedures ... are better accomplished through legislative deliberation than by judicial decree." ${ }^{103}$ The recognition of a new police power is unquestionably a complex legal development, a fact evidenced by the number of important subsidiary issues left unresolved in Mann's wake. The Supreme Court of Canada should have refused to sanction investigative detentions and instead invited Parliament to legislate such a power if, after thorough deliberation on the matter, it thought such a power was needed.

The Supreme Court of Canada justified its foray into the creation of police powers by stating that the Court "cannot ... shy away from the task where common law rules are required to be incrementally adapted to reflect societal change." This begs the question of what "societal change" required the creation of a new police power to detain short of arrest. Increasing crime? More dangerous criminals? Terrorism? We can only speculate because the Court gave no further details. A debate in Parliament might have produced at least some semblance of a policy justification behind the new police power.

Although Parliament was not given an invitation to dialogue by the Supreme Court of Canada, it should not use this as an excuse for inaction. Parliament should pass amendments

\footnotetext{
Delisle, supra note 51 at para 7.

(i) Ibid

11: Canada (Combines investigation Acls. Director of Imvestigation and Rescarch) v. Southam inc.. [1984] 2 S.C.R. 145 at 169.

III. Mann, supra note 2 al para. 17.

Int $\quad$ bid.
} 
to the Criminal Code that eliminate or at least regulate investigative detentions. Realistically, the prospect of Parliament legislating away investigative detentions in the pro-law enforcement atmosphere post-9/11 is slim to none. However, Parliament should not leave the regulation of investigative detentions to the courts. Such an approach will almost certainly lead to an expansion of police powers and a reduction in the freedom of movement of Canadians. 